\title{
Hubungan Antara Derajat Asfiksia dengan Beratnya Hipokalsemia pada Bayi Baru Lahir
}

\author{
Edwin Tohaga, * Kamilah Budhi, * Noor Wijayahadi** \\ ${ }^{*}$ Departemen Ilmu Kesehatan Anak, ${ }^{* *}$ Bagian Farmakologi Fakultas Kedokteran Universitas Diponegoro/ \\ RSUP dr.Kariadi, Semarang
}

\begin{abstract}
Latar belakang. Kalsium merupakan ion yang sangat penting untuk proses metabolisme biomolekular. Selama kehamilan, kalsium ditransfer secara aktif melalui kalsium transplasental yang diregulasi hormon parathyroid-related peptide (PTHrP). Hipokalsemia dapat menyebabkan gangguan neuromuskular, irama jantung apneu, dan gangguan gastrointestinal. Asfiksia dapat menurunkan kadar kalsium darah pada bayi baru lahir di bawah batas nadir. Pada asfiksia terjadi insufisiensi ginjal, metabolik asidosis, dan sekresi parathyroid hormon (PTH) kurang sehingga menurunkan kadar kalsium plasma.

Tujuan. Mengetahui hubungan antara derajat asfiksia dengan beratnya hipokalsemia pada bayi baru lahir Metode. Desain penelitian observasional dengan pendekatan cross sectional pada bayi dengan asfiksia yang memenuhi kriteria inklusi dan eksklusi di bangsal perawatan bayi risiko tinggi Departemen Ilmu Kesehatan Anak RSUP Dr.Kariadi Semarang pada tahun 2012. Derajat asfiksia ditentukan berdasarkan nilai APGAR, yaitu asfiksia sedang dan berat, derajat hipokalsemia ditentukan berdasarkan nilai kadar kalsium serum. Analisis statistik dengan uji chi-square.

Hasil. Subjek 66 bayi terdiri dari 29 bayi laki-laki dan 37 bayi perempuan, 20 bayi lahir kurang bulan dan 46 bayi lahir cukup bulan. Terdapat hubungan antara asfiksia dengan hipokalsemia $(p=0,013)$. Hipokalsemia berat pada asfiksia berat PR 4,9, (IK95\% 1,2-20,3; p=0,027), Hipokalsemia sedang pada asfiksia sedang PR 4,51(IK95\% 1,3-14,6; p=0,009).

Kesimpulan. Terdapat hubungan antara derajat asfiksia dengan beratnya hipokalsemia pada bayi baru lahir. Sari Pediatri 2014;16(1):29-34.
\end{abstract}

Kata kunci: Asfiksia, hipokalsemia

A

sfiksia adalah kegagalan bernapas secara spontan dan teratur segera atau beberapa saat sesudah lahir. ${ }^{1,2}$ Diperkirakan sekitar $23 \%$ dari seluruh angka kematian neonatus

\section{Alamat korespondensi:}

Dr. Edwin Tohaga, SpA. Departemen Ilmu Kesehatan Anak FK Undip/ RSUP Dr. Kariadi, jl. Dr. Sutomo 16 Semarang. E-mail : e_tohaga@ yahoo.com disebabkan oleh asfiksia dengan proporsi lahir mati yang lebih besar. Laporan organisasi kesehatan dunia WHO menyebutkan sejak tahun 2000 - 2003 asfiksia menempati urutan ke- 6 , sebanyak $8 \%$ sebagai penyebab kematian anak di seluruh dunia setelah pneumonia, sepsis, dan kelahiran prematur. ${ }^{1,2}$ Data survey kesehatan rumah tangga (SKRT) 2010 menyebutkan bahwa penyebab kematian bayi baru lahir di Indonesia di antaranya asfiksia $27 \%$, bayi berat lahir rendah 
$29 \%$, tetanus neonatorum $10 \%$, masalah pemberian makanan $10 \%$, gangguan hematologi $6 \%$.

Hipokalsemia adalah suatu kondisi yang dapat menyebabkan gangguan serius, terutama pada bayi baru lahir. Kejadian hipokalsemia merupakan kejadian yang sering terjadi pada bayi lahir yang dapat disebabkan karena terlambatnya fungsi hormon paratiroid dalam metabolisme kalsium pada tubuh bayi. Kalsium merupakan ion yang sangat penting dalam tubuh, bersama dengan fosfor untuk membentuk garam mineral yang membentuk tulang dan gigi. ${ }^{1,3,4}$ Kalsium dalam tubuh $99 \%$ terdapat dalam tulang dan $1 \%$ dalam cairan ektrasel., ${ }^{5}$ Di dalam cairan ektrasel, kalsium terikat dengan albumin (40\%), terikat pada anion seperti fosfor, sitrat, sulfat, dan laktat (10\%) dalam bentuk ion bebas (50\%). Bentuk ion bebas sangat penting untuk proses metabolisme biomolekular, termasuk proses pembekuan darah, eksitabilitas neuromuskular, integritas dan fungsi membran sel, enzim dan aktifitas sekretorik. ${ }^{4,5}$

Kalsium bayi selama dalam kandungan, ditransfer secara aktif dari sirkulasi ibu menuju sirkulasi janin melalui pompa kalsium transplasental yang diregulasi oleh hormon parathyroid-related peptide (PTHrP). Mayoritas transport kalsium janin meningkat pada trisemester ketiga, proses ini menghasilkan peningkatan konsentrasi kalsium lebih tinggi pada janin dibandingkan ibu yang menyebabkan terjadinya hiperkalsemia pada janin, dengan total konsentrasi kalsium berkisar 2,5-2,75 $\mathrm{mmol} / \mathrm{L}$ dan kalsium terionisasi berkisar $1,5 \mathrm{mmol} / \mathrm{L}$ yang dapat diukur pada darah tali pusat bayi cukup bulan. ${ }^{4}$

Hipokalsemia dapat terjadi pada bayi prematur, ibu dengan diabetes, dan bayi yang mengalami asfiksia. Bayi dari ibu diabetes dapat terjadi makrosomia, hipokalsemia dapat disebabkan karena kebutuhan kalsium yang tinggi. Pada bayi prematur, hipokalsemia berhubungan dengan terhentinya transport aktif kalsium selama kehamilan dan pada bayi asfiksia dapat disebabkan adanya insufisiensi ginjal, metabolik asidosis, dan sekresi Parathyroid hormon (PTH) kurang pada saat bayi lahir sehingga menurunkan kadar kalsium plasma. Hipokalsemia sering dihubungkan dengan hipotensi dan gangguan pada irama jantung, gejala yang sering terlihat adalah apneu, takikardi, lethargi, muntah, dan gangguan gastrointestinal. ${ }^{5-7}$ Pada bayi baru lahir dikatakan hipokalsemia apabila kadar kalsium total di bawah $2,00 \mathrm{mmol} / \mathrm{L}$ pada bayi cukup bulan, dan di bawah $1,80 \mathrm{mmol} / \mathrm{L}$ pada bayi preterm. Hipokalsemia ringan apabila nilai kalsium 2,00-2,12 $\mathrm{mmol} / \mathrm{L}$ dapat terlihat tanpa gejala, hipokalsemia sedang apabila nilai kadar kalsium total 1,90-2,00 $\mathrm{mmol} / \mathrm{L}$, dan gejala neuromuskular dapat terlihat pada hipokalsemia berat dengan kadar kalsium $<1,90 \mathrm{mmol} / \mathrm{L}$. ${ }^{4,8,9}$

Asfiksia yang diderita oleh bayi merupakan salah satu faktor risiko terjadinya hipokalsemia. Prevalensi hipokalsemia pada asfiksia adalah 30\%-40\%. ${ }^{10,11}$ Penelitian tentang hubungan antara derajat asfiksia dengan beratnya hipokalsemia sulit dijumpai di kepustakaan Indonesia. Pemahaman mengenai hubungan ini akan sangat membantu untuk memprediksi kejadian hipokalsemia pada bayi baru lahir sehingga dapat dilakukan pencegahan terhadap dampak yang buruk akibat hipokalsemia pada bayi baru lahir.

Penelitian ini bertujuan membuktikan hubungan antara derajat asfiksia dengan beratnya hipokalsemia yang terjadi pada bayi baru lahir.

\section{Metode}

Penelitian observasional dengan desain belah lintang (Cross sectional) yang dilakukan di PBRT (Perawatan Bayi Risiko Tinggi), Divisi Perinatologi Departemen Ilmu Kesehatan Anak FK UNDIP/ RSUP Dr. Kariadi Semarang pada periode bulan Januari - Desember 2012. Penelitian ini telah disetujui Komisi Etik Penelitian Kesehatan Fakultas Kedokteran Universitas Diponegoro dan RSUP dr.Kariadi Semarang dengan nomor 054/EC/FK/RSDK/2013. Analisis statistik yang digunakan untuk menguji hipotesis adalah $\mathrm{Uji}$ chi square

\section{Hasil}

Terdapat 66 subyek bayi, terdiri dari 29 laki-laki dan 37 perempuan, 20 lahir kurang bulan dan 46 lahir cukup bulan. Sembilanbelas bayi mengalami asfiksia berat dan 47 mengalami asfiksia sedang.

Tabel 1 menunjukkan karakteristik demografis subjek. Analisis hubungan antara asfiksia dengan hipokalsemia pada bayi baru lahir dilakukan dengan uji chi square (Tabel 2).

Tabel 2 menunjukkan 66 bayi asfiksia, terdiri 19 $(28,7 \%)$ asfiksia berat dan $47(71,3 \%)$ asfiksia sedang, 
kejadian hipokalsemia 44 (66,7\%). Uji chi square mendapatkan hubungan bermakna antara asfiksia dengan hipokalsemia pada bayi baru lahir $(\mathrm{p}=0,013)$

Analisis hubungan antara asfiksia berat dengan hipokalsemia berat pada bayi baru lahir dilakukan dengan uji Fisher's Exact Test (Tabel 3).

Tabel 3 menunjukkan $19(28,8 \%)$ bayi asfiksia berat, $6(9,1 \%)$ bayi mengalami hipokalsemia berat,

Tabel 1. Karakteristik subyek penelitian

\begin{tabular}{lcc}
\hline Karakteristik & $\begin{array}{c}\text { Asfiksia berat } \\
(\mathrm{n}=19)\end{array}$ & $\begin{array}{c}\text { Asfiksia sedang } \\
(\mathrm{n}=47)\end{array}$ \\
\hline Jenis kelamin (\%) & & \\
$\quad$ Laki-laki & $8(12,1)$ & $21(31,8)$ \\
$\quad$ Perempuan & $11(16,7)$ & $26(39,4)$ \\
Berat lahir (g,\%) & $8(12,1)$ & $9(13,6)$ \\
$\quad<2500$ & $11(16,7)$ & $38(57,6)$ \\
$\geq 2500$ & & \\
Usia kehamilan (bulan, \%) & $8(12,1)$ & $12(18,2)$ \\
$\quad$ Kurang & $11(16,7)$ & $35(53)$ \\
Cukup & & \\
Paritas (\%) & $10(15,2)$ & $30(45,5)$ \\
$\quad$ Primipara & $9(13,6)$ & $17(25,7)$ \\
Multipara & & \\
Cara persalinan (\%) & $11(16,7)$ & $22(33,4)$ \\
SCTP & $5(7,6)$ & $15(22,7)$ \\
Spontan & $3(4,5)$ & $10(15,1)$ \\
Vakum & & \\
Ko insidensi asfiksia (\%) & $2(3)$ & $5(7,6)$ \\
KPD & $4(6)$ & $9(13,6)$ \\
Fetal distress & $1(1,5)$ & $8(12,1)$ \\
Partus macet & $8(12,1)$ & $4(6)$ \\
PEB & & \\
Riwayat ANC (\%) & $10(15,2)$ & $20(30,3)$ \\
Bidan & $9(13,6)$ & $27(40,9)$ \\
Dokter & & \\
\hline
\end{tabular}

Tabel 2. Hubungan antara asfiksia dengan hipokalsemia

\begin{tabular}{|c|c|c|c|c|c|}
\hline \multirow[b]{2}{*}{ Asfiksia } & \multicolumn{3}{|c|}{ Hipokalsemia } & \multirow[b]{2}{*}{ Total } & \multirow[b]{2}{*}{$\mathrm{p}$} \\
\hline & $\begin{array}{c}\text { Berat } \\
\text { n (10) }\end{array}$ & $\begin{array}{l}\text { Sedang } \\
\text { n (34) }\end{array}$ & $\begin{array}{l}\text { Tidak } \\
\text { n (22) }\end{array}$ & & \\
\hline Berat (\%) & $6(9,1)$ & $5(7,6)$ & $8(12,1)$ & $19(28,7)$ & 0,013 \\
\hline Tidak berat (\%) & $4(6,1)$ & $29(43,9)$ & $14(21,2)$ & $47(71,3)$ & \\
\hline Total (\%) & $10(15,27)$ & $34(51,5)$ & $22(33,3)$ & $66(100)$ & \\
\hline
\end{tabular}

Tabel 3. Hubungan antara asfiksia berat dengan hipokalsemia berat

\begin{tabular}{|c|c|c|c|c|c|c|c|}
\hline \multirow[b]{2}{*}{ Asfiksia } & \multicolumn{2}{|c|}{ Hipokalsemia } & \multirow[b]{2}{*}{ Total } & \multirow[b]{2}{*}{$\mathrm{p}$} & \multirow[b]{2}{*}{ PR } & \multicolumn{2}{|c|}{ IK 95\% } \\
\hline & $\begin{array}{l}\text { Berat } \\
\mathrm{n}(10)\end{array}$ & $\begin{array}{c}\text { Tidak berat } \\
\mathrm{n}(56)\end{array}$ & & & & Lower & Upper \\
\hline Berat (\%) & $6(9,1)$ & $13(19,7)$ & $19(28,8)$ & $0,027^{\$}$ & 4,962 & 1,212 & 20,302 \\
\hline Tidak berat (\%) & $4(6,1)$ & $43(65,2)$ & $47(71,2)$ & & & & \\
\hline Total (\%) & $10(15,2)$ & $56(84,8)$ & $66(100)$ & & & & \\
\hline
\end{tabular}


Edwin Tohaga dkk: Hubungan antara derajat asfiksia dengan beratnya hipokalsemia pada BBL

Tabel 4. Hubungan antara asfiksia sedang dengan hipokalsemia sedang

\begin{tabular}{lccccccc}
\hline & \multicolumn{2}{c}{ Hipokalsemia } & & & & \multicolumn{2}{c}{ IK 95\% } \\
\cline { 2 - 3 } \cline { 6 - 8 } Asfiksia & Sedang & Tidak sedang & Total & p & PR & Lower & Upper \\
& $\mathrm{N}(34)$ & $\mathrm{N}(32)$ & & & & & \\
\hline Sedang & $29(44 \%)$ & $18(27,2 \%)$ & $47(71,2 \%)$ & $0,009^{\#}$ & 4,511 & 1,388 & 14,657 \\
Tidak sedang & $5(7,6 \%)$ & $14(21,2 \%)$ & $19(28,8)$ & & & & \\
Total & $34(51,6 \%)$ & $32(48,4 \%)$ & $66(100 \%$ & & & & \\
\hline
\end{tabular}

dan $13(19,7 \%)$ bayi mengalami hipokalsemia tidak berat (normal + hipokalsemia sedang). Sebaliknya, 47(41\%) bayi asfiksia tidak berat (asfiksia sedang), $4(6,1 \%)$ mengalami hipokalsemia berat, dan 43 $(65,2 \%)$ bayi mengalami hipokalsemia tidak berat (normal + hipokalsemia sedang). Uji Fisher's Exact Test menunjukkan terdapat hubungan yang bermakna antara asfiksia berat dengan hipokalsemia berat pada bayi baru lahir. Bayi asfiksia berat memiliki risiko lima kali lebih besar untuk menderita hipokalsemia berat, (IK95\% 1,2-20,3; p=0,018) dibanding bayi asfiksia tidak berat (asfiksia sedang). Hubungan antara asfiksia sedang dengan hipokalsemia sedang pada bayi baru lahir dianalisis dengan uji chi square (Tabel 3).

Tabel 4 menunjukkan pada $47(71,2 \%)$ bayi asfiksia sedang terdapat $29(44 \%)$ bayi yang mengalami hipokalsemia sedang dan $18(27,2 \%)$ bayi mengalami hipokalsemia tidak sedang (normal + hipokalsemia berat). Sebaliknya, pada 19 (28,7\%) bayi asfiksia tidak sedang (asfiksia berat) terdapat $5(7,6 \%)$ mengalami hipokalsemia sedang dan $14(21,2 \%)$ bayi mengalami hipokalsemia tidak sedang (normal + hipokalsemia berat). Uji chi square menunjukkan terdapat hubungan bermakna antara asfiksia sedang dengan hipokalsemia sedang pada bayi baru lahir. Bayi asfiksia sedang memiliki risiko 4,5 kali lebih besar untuk menderita hipokalsemia sedang (IK95\% 1,3-14,6; p=0,018) dibanding bayi asfiksia tidak sedang (asfiksia berat).

\section{Pembahasan}

Kadar kalsium serum relatif lebih tinggi pada saat kelahiran dan akan menurun dengan cepat pada jam-jam pertama akan mencapai titik nadir pada 2448 jam. Penurunan ini disebabkan oleh terhentinya (penjepitan tali pusat) transport aktif kalsium dari plasenta (trimester ke-3). Berbagai kondisi dapat memperburuk kondisi ini seperti kelahiran prematur, asfiksia, dan ibu menderita DM. ${ }^{4,8,9}$

Hasil penelitian ini menunjukkan bahwa kejadian hipokalsemia pada bayi asfiksia cukup tinggi. Hasil ini lebih tinggi dari hasil penelitian Tsang $\mathrm{dk},{ }^{11}$ yaitu 30\%$40 \%$. Hal tersebut menunjukkan bahwa hipokalsemia cukup sering ditemukan pada bayi asfiksia sehingga pemeriksaan kalsium perlu dilakukan pada bayi asfiksia karena hipokalsemia dapat menyebabkan kejang yang membahayakan hidup bayi. ${ }^{5-7}$

Didapatkan hubungan antara asfiksia dengan kejadian hipokalsemia pada bayi baru lahir. Sesuai dengan hasil penelitian Onyiriuka ${ }^{10}$ dan Tsang $\mathrm{dkk}^{11}$ yang mendapatkan hasil adanya hubungan antara asfiksia dengan kejadian hipokalsemia. Sebaliknya, Dewi $\mathrm{dkk}^{26}$ mendapatkan hasil yang berbeda bahwa asfiksia tidak berhubungan dengan kejadian hipokalsemia. Perbedaan ini sangat mungkin disebabkan karena bayi asfiksia yang mengalami hipokalsemia hanya $10 \%$, hal ini tentunya akan memengaruhi hasil perhitungan.

Penelitian ini menggunakan data rekam medis yang menilai asfiksia dan derajat asfiksia menggunakan nilai APGAR dengan analisis gas darah pada 66 subyek yang menunjukkan tanda hipoksia. Nilai APGAR banyak digunakan di beberapa rumah sakit maupun para peneliti. Penggunaan nilai APGAR secara tunggal tidak disarankan karena sensitifitasnya yang rendah dan diperlukan beberapa indikator pendamping lainnya, di antaranya adalah $\mathrm{pH}$ darah. ${ }^{25} \mathrm{Namun}$, Casey $\mathrm{dkk}^{14}$ melaporkan bahwa penggunaan nilai APGAR sebagai indikator asfiksia masih banyak dilakukan dan masih merupakan rujukan untuk mendiagnosis asfiksia.

Hubungan antara asfiksia berat dengan hipokalsemia berat menunjukkan $(28,8 \%)$ bayi asfiksia berat, $6(9,1 \%)$ mengalami hipokalsemia berat dan $13(19,7 \%)$ mengalami hipokalsemia tidak berat (normal + hipokalsemia sedang). Hasil analisis menunjukkan terdapat hubungan antara asfiksia berat dengan hipokalsemia berat, dan bayi asfiksia berat memiliki risiko 5 kali lebih besar untuk menderita 
hipokalsemia berat dibanding bayi asfiksia tidak berat (asfiksia sedang). Hal tersebut berbeda pada penelitian yang dilakukan oleh Onyiriuka ${ }^{10}$ yang mendapatkan kejadian hipokalsemia pada asfiksia berat sebesar $22,6 \%$. Terdapat hubungan antara asfiksia sedang dengan hipokalsemia sedang dan bayi asfiksia sedang memiliki risiko 4,5 kali lebih besar untuk menderita hipokalsemia sedang dibanding bayi asfiksia tidak sedang (asfiksia berat).

Rerata kadar kalsium total bayi asfiksia berat tidak berbeda dibandingkan rerata kadar kalsium total bayi asfiksia sedang. Hasil tersebut berbeda dengan penelitian terdahulu oleh Onyiriuka ${ }^{10}$ dan Tsang dkk ${ }^{11}$ yang melaporkan rerata kadar kalsium total lebih rendah pada bayi asfiksia berat dibandingkan pada asfiksia sedang.

Kasus BBLR 13 (19,7\%) bayi mengalami hipokalsemia, $7(10,6 \%)$ di antaranya hipokalsemia berat dan $6(9,1 \%)$ hipokalsemia sedang. Pada bayi $>2500$ gram, 31 (47\%) bayi mengalami hipokalsemia, 3 $(4,5 \%)$ di antaranya hipokalsemia berat dan $28(42,4 \%)$ hipokalsemia sedang. Hasil analisis menunjukkan tidak ada hubungan antara berat badan lahir dengan kejadian hipokalsemia. Sesuai dengan penelitian Dewi dkk, ${ }^{26}$ tetapi berbeda dengan Tsang $\mathrm{dkk}^{11}$ yang melaporkan bahwa berat badan lahir sebagai salah satu faktor risiko terjadinya hipokalsemia pada bayi baru lahir.

Tanda klinis hipokalsemia berat yaitu kejang dan carpopedal spasme pada subjek penelitian ini tidak terlihat. Onyiriuka melaporkan bahwa tanda-tanda tersebut bukan merupakan tanda klinis utama dan terlihat apabila kadar kalsium serum $<1,90 \mathrm{mmol} / \mathrm{L}$ (hipokalsemia berat). Pada penelitian ini terdapat $10(15,2 \%)$ bayi asfiksia dengan hipokalsemia berat (kadar serum <1,90 $\mathrm{mmol} / \mathrm{L}$ ) dan tidak terlihat gejala kejang maupun carpopedal spasme, dimungkinkan karena kadar kalsium terionisasi tidak diperiksa. Kadar kalsium terionisasi merupakan parameter utama yang menyebabkan timbulnya gejala klinis pada bayi dengan hipokalsemia berat. ${ }^{7,8,12,19}$ Albumin sebagai salah satu protein yang mengikat kalsium berpengaruh terhadap nilai kadar kalsium serum, perlu dilakukan penyesuaian nilai kalsium serum apabila terdapat penurunan kadar albumin. ${ }^{5,8}$

Hasil dari penelitian ini menunjukkan terdapat hubungan antara derajat asfiksia dengan beratnya hipokalsemia. Hasil tersebut berbeda dengan penelitian Dewi $\mathrm{dkk}^{26}$ yang melaporkan tidak ada hubungan antara derajat asfiksia dengan kejadian hipokalsemia.
Bayi kurang bulan (prematur) berisiko untuk mengalami hipokalsemia saat lahir terutama gestasi $<32$ minggu, sebab tidak mengalami transport aktif kalsium dari ibu saat trimester ke-3. Penelitian ini mengikutsertakan 13 bayi kurang bulan (5 bayi gestasi <32 minggu) untuk mencukupi jumlah sampel penelitian dan telah dianalisis pengaruhnya terhadap kejadian hipokalsemia yang ternyata tidak ada hubungan antara subyek bayi kurang bulan dengan kejadian hipokalsemia. Hal tersebut sesuai dengan penelitian Dewi $\mathrm{dkk}^{26}$ yang menyatakan bahwa usia paritas tidak berhubungan dengan hipokalsemia.

Perbedaan hasil penelitian ini dengan peneliti lain sangat mungkin disebabkan karena peneliti tidak membahas hubungan antara asfiksia dengan kadar kalsium terionisasi dan kadar albumin yang memengaruhi kadar kalsium darah. ${ }^{10}$ Selain itu, peneliti lain tidak menyinggung data analisis gas darah yang memengaruhi kondisi hipoksia, berdampak pada nilai kadar kalsium.

Keterbatasan penelitian ini adalah tidak menilai kadar kalsium terionisasi dan kadar albumin yang memengaruhi kadar kalsium darah.

\section{Kesimpulan}

Terdapat hubungan antara derajat asfiksia dengan beratnya hipokalsemia pada bayi baru lahir. Pada bayi asfiksia, perlu pemberian kalsium glukonas setelah lahir untuk mengantisipasi timbulnya gejala hipokalsemia, dan dilakukan pemeriksaan kadar kalsium darah untuk mengevaluasi terapi. Diperlukan penelitian lebih lanjut dengan memperhatikan faktor yang berpengaruh terhadap kadar kalsium

\section{Daftar pustaka}

1. Ronald S, Bloom M, Cropley C. Texbook of neonatal resuscitation. Edisi ke-6: American Academy of Pediatrics 2011.h.1-10.

2. Departemen Kesehatan Republik Indonesia. Riset Kesehatan Dasar 2010. (Internet) (diakses Mei 2013 ) Didapat dari: http://www.litbang.depkes.go.id/.

3. Lawn cs, Zupan. 4 million neonatal deaths: When?, Where? Why. Lancet 2005;3:891-900.

4. Seri I, Ramanathan R, Evans JR. Acid-base, fluid, and electrolyte management. Dalam: Avery's diseases of the 
newborn.Taeusch, Ballard, Gleason, penyunting. Edisi ke-8. Philadelphia: Elsevier Saunders;2005.h.372-6.

5. Brown EM. Calcium receptor and regulation of parathyroid hormone secretion. Boston: Kluwer Academic Publisher; 2000.h.30-40.

6. Horne H S. Fluid, electrolite and acid-base balance. Edisi ke-5. St Louis, Missouri: Mosby-year book, Inc; 2004.h.107-30.

7. Zhou P, Adam. Hipocalcemia in infants and children. Pediatr in Rev 2009;30:190-2.

8. Mimouni F, Tsang. Neonatal hypocalcemia:to treat or not to treat? J AM Coll Nutr 1994;13:408-15.

9. Aggarwal R U, Deodari AK, Paul VK. Hypocalcemia in the newborn. Indian J Pediatr 2008;75:165-9.

10. Onyiriuka AN. Prevalence of neonatal hypocalsemia among full-term infants with severe birth asphyxia. Pac J Med Sci 2010;8:3-12.

11. Tsang RC, Chen I, Hayes W, Atkinson W, Atherton $\mathrm{H}, \mathrm{N}$ E. Neonatal hypocalcemia in infants with birth asphyxia. Fetal and Neonatal Med 1974;84:428-33.

12. Hsu SC, Levine MA. Perinatal calsium metabolism: physiology and pathophysiology. Pediatric Endocrinol Rev 2003;9:23-36.

13. Urbano FL. Sign of hypocalcemia: chvostec's and trousseau's sign. Hospital Physician 2000:43-5. (diakses 15 Mei 2009). Didapat dari: www.turner-white.com/pdf hp_marO0_hypocal.pdf.

14. Casey BM DD, Mcintire, Kenneth J,Leveno KJ. The continuing value of apgar score for the assessment of newborn infants. The New England J Med 2001;344:46771.

15. Finster M, Wood M. The apgar score has survived the test of time. Anesthesiology 2005;102:855-7.

16. Moster D LR, Maskertad T. Joint association of apgar score and early neonatal symptoms with minor disabilities at school age. Arch Dis Child Fetal Neonatal 2002;86:16-21.
17. Oswin G VJ, Friesen H. Perinatal asphyxia at Port Moresby General Hospital : a study of incidence, risk faktor and outcome. PNG Med J 2000;43:110-20.

18. Soetomenggolo TS. Buku ajar neurologi anak. Edisi ke2. Soetomenggolo TS, penyunting. Jakarta: BP IDAI; 2000.h.307-38.

19. Volve JJ. Neonatal seizures. Dalam: Volpe JJ, penyunting. Neurology of the newborn. Edisi ke-4. Philadelphia: WB Saunders Company; 2001.h.459-61.

20. Shah P RS, Beyene J, Perlman M. Multiorgan dysfunction in infants with post-asphyxial hypoxic-ischaemic encephalopathy. Arch Dis Child Fetal Neonatal 2004;89:152-5.

21. Oswin G VJ, Friesen H. Perinatal Asphyxia at Port Moresby General Hospital : A study of Incidence, Risk Faktor and Outcome. PNG Med J 2000;43:110-20.

22. Matthew E NM, Dharma S, Anthony M. Risk faktors for neonatal encephalopathy in Kathmandu, Nepal, a developing country: unmatched case-control study. BMJ 2000;320:122901236.

23. Christopher S. Kovacs HM, Kronenberg. Maternalfetal calsium and bone metabolism during pregnancy, puerperium, and lactation. Endocr Rev 1997;18:83272.

24. Madiyono B MS, Sastroasmoro S, Budiman I, Purwanto SH. Dasar-dasar metodologi penelitian klinis. Edisi ke-3. Sastroasmoro S IS, penyunting. Jakarta: Sagung Seto; 2008.h.45-50.

25. Cunningham FG. The New Born Infant. In Willian Obstetrics. Cunningham FG, Leveno KJ, Bloom SL, Houth JC, Rousie DJ, penyunting. Edisi ke-23. New York: McGrow-Hill Companies;2003.h.605-13.

26. Dewi R, Rohsiswatmo R. Faktor yang Mempengaruhi Angka Kejadian Hipokalsemia di Ruang Rawat Neonatal. J Indon Med Assoc 2012;62:386-90. 